\title{
Penerapan Pola Asuh Orang Tua sebagai Strategi Belajar untuk Meningkatkan Efektivitas Pembelajaran di Masa Pandemi
}

\author{
Kiki Maulina \\ Program Studi Pendidikan Guru Sekolah Dasar, Fakultas Keguruan dan Ilmu Pendidikan \\ Universitas Muhammadiyah Prof. Dr. Hamka, Email: kikimaulina90@gmail.com \\ Lina Riyani \\ Program Studi Pendidikan Guru Sekolah Dasar, Fakultas Keguruan dan Ilmu Pendidikan \\ Universitas Muhammadiyah Prof. Dr. Hamka, Email: linariyani21@gmail.com \\ Mira Destyaningrum \\ Program Studi Pendidikan Guru Sekolah Dasar, Fakultas Keguruan dan Ilmu Pendidikan \\ Universitas Muhammadiyah Prof. Dr. Hamka, Email: miradestya03@gmail.com \\ Yofie Nur Faaiqah \\ Program Studi Pendidikan Guru Sekolah Dasar, Fakultas Keguruan dan Ilmu Pendidikan \\ Universitas Muhammadiyah Prof. Dr. Hamka, Email: yofienurfaaiqah@gmail.com

\section{Zulherman} \\ Program Studi Pendidikan Guru Sekolah Dasar, Fakultas Keguruan dan Ilmu Pendidikan \\ Universitas Muhammadiyah Prof. Dr. Hamka, Email: zulherman@uhamka.ac.id
}

\begin{abstract}
Abstrak
Masa pandemi ini anak-anak belajar dirumah dengan cara belajar online, selain itu belajar tanpa bimbingan guru penggantinya ialah orang tua untuk mengajarkan atau mengarahkan dalam pembelajaran online ini agar tujuan pembelajaran secara efektif tercapai, bahwasanya pembelajaran online ini sangatlah tidak mudah masih banyak orang tua yang mengeluh dengan pembelajaran online ini. Penilitian ini memiliku tujuan untuk mengetahui hubungan pola asuh orang tua dimasa pandemi ini agar siswa selama belajar di rumah lebih semangat dan belajar secara efektif seperti pembelajaran disekolah. Penilitian ini menggunakan metode penelitian smartpls untuk mengumpulkan data yaitu angket. Dengan cara menyebarkan link terhadap orang tua yang memiliki anak bersekolah. Dengan adanya penelitian ini menunjukan bahwa terdapat adanya memiliki hubungan yang positif dalam pola asuh orang tua terhadap anak nya dalam motivasi belajar siswa. Bahwasannya ada nya sekolah online atau dirumah ini selama pandemi belajar berjalan secara efektif seperti belajar disekolah.
\end{abstract}

Kata Kunci : pola asuh orang tua, mengembangkan strategi belajar, pembelajaran lebih efektif

\section{PENDAHULUAN}

Masa pandemic covid-19 ini membuat semua orang merubah pola hidupnya serta pada pola pendidikan yang berubah. Dalam kondisi pandemic covid-19 dilibatkan secara bersamaan dengan era revolusi industri 4.0 (Kurnianto \& Rahmawati, 2020). perubahan cara belajar saat ini sangatlah memaksa pola pikir Pendidikan untuk mengikuti peraturan pembelajaran pada masa pandemi covid 19 dengan memanfaatkan media teknologi dalam pembelajaran online yang dimana adanya perkembangan teknologi informasi. Menurut (DARING, 2021) dimasa pandemic tidak diberlakukan untuk sekolah offline ataupun tempat - tempat lainnya untuk bersosialisasi secara langsung dengan pendidik.

Bahwasannya Pendidikan memiliki arti memelihara dan membentuk karakter seseorang dalam proses pembelajaran berlangsung serta dapat mengubah tingkah laku dan pendewasaan terhadap siswa secara individu atau kelompok (Putro, Khamim, 2020). Peranan orang tua sangatlah berpengaruh pada kehidupan anak dimasa pandemic sekarang ini, pada awalnya orang tua hanya berperan untuk mendidik dan menemaninya saja dengan kemampuan dasar yang dimiliki orang tua, namun semakin lama orangtua memiliki peran yang lebih luas 
menjadikan pendamping akademik siswa. Menurut (Laana, 2021) keterpautan hubungan orang tua dengan anaknya sangat berpengaruh pada nilai - nilai yang ada pada diri anak.

Sedangkan menurut pendapat (Siregar, 2013: 8) peran orang tua dalam meningkatkan pendidikan anak terdapat empat cara yaitu, Pertama, membuat rancangan kegiatan seorang siswa serta waktu siswa. Anak yang telah diajarkan guru diberi waktu untuk mengulangi pelajaran pada hari itu. Kedua, melihat perkembangan akademik anak, Guru meminta wali murid untuk memvalidasi hasil tes dan tugas - tugas pada anak. Ketiga, melihat perkembangan anak muridnya tentang kepribadiannya. Keempat, memantau kegiatan anak waktu di sekolah. (Lilawati, 2020) Peran oran tua saat dirumah sangatlah membantu para guru dalam melaksanakan pembelajaran secara mandiri, maka dari itu orang tua menjadi lebih memiliki pengalaman tersendiri dalam mendampingi anak - anaknya (Azizah, 2020).

Peran orang tua dalam proses pembelajaran ini harus dilaksanakan secara maksimal seperti pembelajaran disekolah, meskipun pada dasarnya orang tua memiliki kelebihan dan kekurangannya tersendiri, namun para orang tua diharuskan untuk mengajar dengan sabar dan teliti. Menurut (Zulfitria, n Ansharullah, 2020) Media pembelajaran secara online ini berupa What'sApp, zoom, google meet, classroom, dll. Menurut (Sundari, 2017) peran pendidik dalam proses belajar ialah sumber belajar siswa, serta sebagai fasiliator, agar membimbingan anak selama pembelajaran serta peran orang tua dengan bertujuan untuk keaktifan pada siswa. Pembelajaran daring sebuah penanganan belajar mengajar yang bermutu.

Anak memiliki sebuah motivasi yang sifatnya sementara disebabkan kurangnya dukungan dari lingkungan sekitar, apabila anak sudah mulai bosan maka sebaiknya guru atau orang tuanya memberi pemahaman serta pengertian yang lebih pada anak, maka dari itu para orang tua akan ikut belajar bertujuan untuk lebih pandai dalam mencairkan suasana untuk mengajarkan anaknya dirumah dimasa pandemic dengan hal yang menarik. Metode bermain bisa menjadi salah satu cara pembelajaran yang menarik dan bisa diterapkan dirumah.

Cara orang tua ntuk meningkatkan perkembangan kognitif anak pada masa pandemi saat ini dapat memberikan konsep pembelajaran yang mampu membuat anak berfikir kritis mengasah pengetahuan anak dalam bentuk pemahaman berbeda dan orang tua dapat membantu anak untuk menyiapkan media yang bisa digunakan anak serta berbagai aktivitas yang bisa memaksimalkan proses pembelajaran daring di rumah. (Lilawati, 2020)

Ada beberapa faktor yang menyebabkan pembelajaran online terbilang kurang maksimal, karena pendidik masih beradaptasi tentang pembelajaran online ini atau kurangnya media yang interaktif dalam mengajarkan peserta didikorang tua memiliki karakteristik yang berbeda-beda hal ini sebagai factor mempengaruhi pola asuh peserta didik. Menurut (Sutrah, 2021) orang tua setiap orang memiliki sikap yang berbeda- berbeda dalam kepribadiannya untuk mendidik anaknya.

Tujuan penelitian adalah menjawab beberapa pertanyaan:

Apakah pembelajaran dirumah dalam masa pandemi covid 19 menyenangkan?

Apakah materi yang diberika oleh guru bisa menerima dengan baik oleh siswa/siswi?

Apakah selama pembelajaran dirumah peran orang tua sangat penting?

Adakah kesulitan dipembelajaran selama belajaran dirumah?

Apakah orang tua siswa dapat melakukan strategi pembelajaran dirumah dengan maksimal? 
Apakah orang tua siswa sudah melakukan pola asuh yang baik pada anak agar pembelajaran tercapai?

\section{METODE}

Jenis penelitian ini menggunakan penelitian kuantitatif, karena penelitian ini menggunakan perhituangan metode statistik untuk pengumpulan data. Hasil data penelitian didapatkan melalui responden orang tua siswa sekolah dasar. Penelitian ini dilaksanakan untuk mengetahui kemampuan pola pikir siswa melalui penerapan pola asuh orang tua siswa.

Teknik pengumpulan data menggunakan survey seacara onling dengan menggunakan aplikasi goggle form. Karena dimasa pandemic saat ini aplikasi ini sangat mempermudah untuk melaksanan penelitian secara online. Penelitian ini menggunakan teknik analisis inferensial, teknik ini digunakan untuk menganalisis data statistic dalam memperolah perhitungan dalam membuat kesimpulan data.

Teknik validasi data dengan menggunakan aplikasi Smart PLS, dengan menggunakan aplikasi ini dapat membantu untuk menghitung setiap validasi data yang sudah didapatkan serta dengan menggunakan Smart PLS dapat membuktikan kesesuaian datadata.

Pengambilan data dengan menggunakan goggle form secara online. Dengan menyebarkan link goggle form melalui aplikasi whats app. Pertanyaan dalam angket goggle form sebanyak 10 pertanyaan dengan 5 skala yaitu (Sangat setuju) nilainya 5 , (setuju) nilainya 4, (Kurang setuju) nilainya 3, (Tidak setuju) nilainya 2, ( Sangat tidak setuju) nilainya 1 dan Jumlah responden terdiri dari 90 orang tua wali murid.

Point-point yang dibahas dalam penelitian ini ialah :

1. Pola asuh orang tua
2. Strategi Pembelajaran

3. Pembelajaran efektif

Data survey ini dilakukan pada dunia pendidikan dimasa pandemic agar dapat menggambarkan pola asuh orang tua terhadap anak dimasa pandemi saat ini, tidak dapat dipungkiri bahwasannya dalam setiap teori-teori yang diteliti juga memiliki efek terhadap anak.

Sekarang anak bersekolah dengan jarak dan teknologi dengan penelitian ini dapat diketahu bagaimana pola asuh orang tua agar memilki strategi pembelajaran dirumah yang akan menjadikan pembelajaran lebih efektif walaupun mereka banyak belajar dari rumah. Itu semua peran orang tua sangatlah berpengaruh.

Data survey dikelola melalui aplikasi Smart PLS untuk menguji secara signifikan antara pola asuh orang tua dengan strategi pembelajaran yang akan mengakibatkan pembelajaran yang efektif di masa pandemic..

Berikut adnya syarat dalam melakukan analisis yaitu,

1. Dengan syarat penilitian ini menggunakan Convergent validity; yaitu pengukur variabel disebut dengan indicator dengan nilai indikatornya harus mencapai lebih dari 0.70 .

2. Kemudian pada pengukuran reliabilitas konstruk yang sudah dianggap sesuai syarat yaitu yang sudah memiliki nilai diatas 0,70 .

3. Pada Average variance extracted ada beberapa sesuai dengan ketentuannya yaitu 0,70 .

4. Dan untuk persyaratan nilai validitas diskrimanan harus mencapai nilai 0,50 sehingga syaratnya terpenuhi.

\section{HASIL DAN PEMBAHASAN}

Survey penilitian mengasilkan analisis dengan menggunakan Smart PLS Hubungan antara Pola Asuh (PO), Strategi Pembelajaran 
(SP), dan Pembelajaran Efektif (PE) .

Adanya hasil analisis pengaruh Pola Asuh Orang tua terhadap Strategi Pembelajaran dan Pembelajaran Efektif

\begin{tabular}{|c|c|c|c|c|c|c|}
\hline \multicolumn{2}{|c|}{ Mean, STDEV, T-Values, P-Val... } & \multicolumn{2}{|c|}{ Confidence Intervals } & \multicolumn{2}{|c|}{ Confidence Intervals Bias Cor... } & \multirow{2}{*}{\begin{tabular}{|l} 
PVampl \\
PValues
\end{tabular}} \\
\hline & Original Sampl... & Sample Mean (... & Standar & rd Devia.... & TStatistics $(10 \ldots .$. & \\
\hline$P O \rightarrow P E$ & $-0,016$ & 0.072 & & 0,325 & 0.050 & 0.960 \\
\hline$P O \rightarrow S P$ & 0.330 & 0.319 & & 0.164 & 2.015 & 0.044 \\
\hline$S P \rightarrow P E$ & 0,348 & 0.259 & & 0.207 & 1.678 & 0.094 \\
\hline
\end{tabular}

Hasil data variabel pola asuh terhadap variabel strategi pembelajaran memiliki nilai sebesar 0,330 sehingga kedua variable tersebut saling berpengarauh . Jadi dapat disimpulakan pada kedua variable ini bahwa setiap pola asuh yang diberikan orang tua terhadap anak maka strategi pembelejaran yang didapatkan anak akan membantu anak dalam mencapai tujuan pembelajaran dengan baik.

Perhitungan dapat dilaksanakan dengan menggunakan bootstrap atau resampling, hasil pengujiannya yaitu Pola Asuh Terhadap Strategi Pembelajaran dengan menggunakan bootstrap memiliki data hasil sebesar 0,319 kemudian dengan menggunakan nilai hitungan $T$ mendapatkan hasil sebesar 2,015 maka $P$ Value ialah 0,044 $<0,05$ sehingga di terimanya H1 atau dapat disimpulkan bahwa $\mathrm{H} 1$ berpengaruh langsung dalam Pola Asuh terhadap Strategi Pembelajaran yang saling berkesinambungan. secara statistik.Maka dari itu, sangat penting bagi orang tua dalam meningkatkan Pola Asuh yang baik untuk anaknya demi meningkatkan Strategi Pembelajaran.

Pola Asuh pengaruhnya terhadap Pembelajaran Efektif itu kecil, dengan $\mathrm{P}$ Valuenya $0,960>0,05$ sehingga terjadinya ketidak signifikan antara kurangnya pola asuh dari orang tua sehingga berpengaruh dalam pembelajaran yang efektif pada anak dan masih banyak faktor lain yang dapat mempengaruhi terhadap Pembelajaran Efektif terhadap anak.

Pada Strategi Pembelajaran pengaruh terahadap Pembelajaran Efektif $\mathrm{p}$ valuenya 0,094> 0,05 maka, penilainnya tidak signifikan. Karena Pembelajaran Efektif tidak hanya dari startegi pembelajaran saja tetatpi banyak factor yang mempengaruhi agar dapat menjadikan pembelajaran efektif.

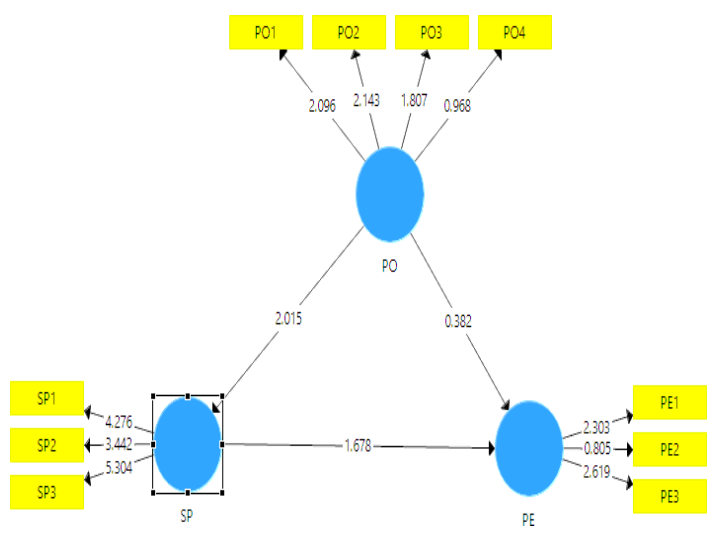

Gambar Diagram 1.

Hasil analisis hubungan antara PO,SP dan PE

Pada PO hanya ada empat saja untuk meningkatkan Pola Asuh orang tua terhadap anak. Dalam hal ini orang tua sangat berperan pentiing dalam membentuk pola asuh anak agar pembelajaran tercapai dengan baik. Orang tua saat membentuk pola asuh anak harus memberikan perhatian yang lebih pada anak tersebut agar anak bisa mengikuti pembelajaran dengan baik walaupun di masa pandemic saat ini dimana pembelajaran di sekiah dilakukan dengan jarak jauh dengan posisi anak hanya dirumah saja, maka dari itu pentingnya pola asuh orang tua terhadap anak.

Dengan orang tua telah melakukan Pola Asuh dengan benar maka startegi pembelajaran akan terbentuk dengan baik pula. Dimana stratgei pembelajaran juga salah satu bagain penting agar pembelajaran tercapai dengan baik. Agar pemebelajaran efekif bisa dilaksanakan, 
tidak hanya dari strategi pembelajaran saja tetapi banyak factor-faktor yang menyebabkan pembelajaran efektif di masa pandemic saat ini yaitu dengan factor guru, factor sikap dan factor lingkungan.

\section{PENUTUP}

\section{Simpulan}

Masa pandemi ini orang tua sangat berpengaruh dalam pembelajaran online, pola asuh orang tua sangatlah membantu untuk pencapaian pembelajaran anak. Apabila strategi orang tua yang diberikan anak salah, maka strategi tidak tercapai, oleh karena itu dimasa pandemic ini guru serta orang tua untuk bekerja sama agar tujuan pembelajaran online tercapai dan membuat pembelajaran anak lebih efektif.

\section{Saran}

Berdasarkan dari pembahasan penilitan ini, agar orang tua dapat mengawasi dan membantu pembelajaran online serta bimbingan orang tua sangat membantu para anak agar mudah mengerti dalam pembelajaran. Adapun cara untuk membantu agar anak tetap tetap termotivasi dalam belajar seperti halnya kecerdasan emosional memiliki 5 aspek seperti (kesadaran diri pengaturan diri, motivasi, empati dan keterampilan sosial), pengambil keputusan yaitu bagaimana anak bisa berpikir secara kritis dan dapat memecahkan masalah yang ada. Sehingga pembelajaran online menjadi efektif.

\section{DAFTAR PUSTAKA}

Azizah, L. K. (2020). Pengaruh Peran Orang Tua Terhadap Keaktifan Belajar Siswa pada Masa Pandemi Covid-19 di MIN 02 Madiun Kabupaten Madiun Tahun Pelajaran 2020/2021.

DARING. (2021).
Kurnianto, B., \& Rahmawati, R. D. (2020). Hubungan Pola Asuh Orang Tua terhadap Motivasi Belajar Siswa Pada Pembelajaran Daring Masa Pandemi. Sendika, 2, 1-11.

Laana, D. L. (2021). Solusi Orang Tua dalam Meningkatkan Minat Belajar Anak secara Daring pada Masa Pandemi Covid-19. 1(1), 79-90.

Lilawati, A. (2020). Peran Orang Tua dalam Mendukung Kegiatan Pembelajaran di Rumah pada Masa Pandemi. Jurnal Obsesi: Jurnal Pendidikan Anak Usia Dini, 5(1),549.

https://doi.org/10.31004/obsesi.v5i1.630

Pemimpin, K., Efektivitas, D., Di, S., \&Wening, N. (n.d.). Dampak Kecerdasan Emosi Terhadap Kualitas Pengambilan. 5(1), 59-66.

Putro, Khamim, dkk. (2020). Pola interaksi anak dan orangtua selama kebijakan pembelajaran di rumah. Fitrah: Jurnal of Islamic Education, 1(1), 124-140.

Sundari, F. (2017). Peran Guru Sebagai Pembelajar Dalam Memotivasi Peserta Didik Usia SD. Prosiding Diskusi Panel Pendidikan "Menjadi Guru Pembelajar" Keluarga Alumni Universitas Indraprasta PGRI, (April), 60-76.

Sutrah, A. (2021). Peran Orang Tua dalam Pembelajaran Anak di Masa Pandemi. http://dx.doi.org/10.31219/osf.io/nsv42

Zulfitria, Ansharullah, C. A. P. (2020). Pentingnya Peran Orang Tua dalam Pendampingan Pembelajaran Daring di Masa Pandemi Covid-19. Prosiding Seminar Nasional Penelitian LPPM $U M J$, 2-6. https://jurnal.umj.ac.id/index.php/semnasli t/article/view/8797/5152 